\title{
MusicMatic - The French Supreme Court's Decision on Creative Commons Plus (CC+) Commercial Licensing and Mandatory Collective Management of the Right to Remuneration for Communication to the Public of Commercial Phonograms
}

\section{Oleksandr Bulayenko}

Published online: 4 June 2020

(C) The Author(s) 2020

\begin{abstract}
The French Supreme Court established that businesses using on their premises devices provided by third parties for making background music are performing an act of communication to the public in the sense of Art. L214-1 of the French Intellectual Property Code (CPI). The Court qualified commercially licensed phonograms, also published under Creative Commons non-commercial licences (CC BY-NC-ND 3.0) on the Jamendo online platform, as "phonograms published for commercial purposes". According to the Court, the right to remuneration for communication to the public of phonograms published for commercial purposes cannot be contractually waived by performers. The right to remuneration is subject to mandatory management by a collective management organisation (CMO) regardless of whether rightholders have explicitly contractually entrusted the exercise of their rights to the CMO. Mandatory collective management of the right to remuneration for communication to the public of phonograms published for commercial purposes is compatible with EU law. The Supreme Court declined to refer the question of the compatibility of mandatory collective management to the Court of Justice of the European Union (CJEU), considering that the law is sufficiently clear in this regard.
\end{abstract}

Keywords Copyright and related rights - Equitable remuneration · Mandatory collective management $\cdot$ Creative Commons · France $\cdot$ Music $\cdot$ Phonograms published for commercial purposes

\footnotetext{
O. Bulayenko $(\bowtie)$

Dr.; Researcher and Academic \& Scientific Coordinator, Centre for International Intellectual Property Studies (CEIPI), University of Strasbourg, Strasbourg, France e-mail: bulayenko@ceipi.edu; o.bulayenko@uva.nl
}

\section{O. Bulayenko}

Associated Researcher, Institute for Information Law (IViR), University of Amsterdam, Amsterdam, The Netherlands 


\section{Introduction}

The dispute opposed a group of European companies specialised in offering background music services to businesses with premises receiving the public (e.g. shops, hotels, fitness clubs) and French collective management organisations (CMOs) involved in the collection of remuneration for communication to the public of phonograms. The group of the music business companies was composed of AudioValley (a Belgian company and owner of Storever, formerly MusicMatic), Storever France (a French company, formerly MusicMatic France) and Jamendo (a Luxembourgish company). For the purpose of brevity, this group of related companies will henceforth be referred to as the "MusicMatic Group".

In 2009, MusicMatic France concluded a contract with Tapis Saint Maclou, a company having over a hundred stores around France, specialised in the sale of decoration of floors and interiors of houses. Under the terms of the contract, MusicMatic France undertook to provide against payment the stores of Tapis Saint Maclou with devices enabling personalised programmes of background music "free of public communication rights" ("libre de tous droits de diffusion"). MusicMatic's business model was based on licensing music released under Creative Commons (CC) non-commercial licences and offered through the Jamendo Licensing platform with additional permissions enabling commercial use.

In 2013, Tapis Saint Maclou received a claim from SACEM (Société des auteurs, compositeurs et éditeurs de musique), a French CMO, for over 100,000 euros for communication to the public of music phonograms in the company's stores. MusicMatic France became involved because, according to the terms of the mentioned contract, it provided Tapis Saint Maclou with a guarantee against copyright claims by SACEM, specifically, or any other party. Other members of the MusicMatic Group joined the dispute.

In the lower instances, Tapis Saint Maclou was condemned to pay and MusicMatic to bear the guarantee of the payment. ${ }^{1}$ The contract between the parties was resolved due to the fault of MusicMatic France. The final word in the case was spoken by the French Supreme Court (Cour de cassation) on 11 December 2019, confirming the judgments of the lower instance courts. ${ }^{2}$

The present case note discusses the following issues raised in the course of the proceedings before the Supreme Court and lower instance courts:

- Are phonograms published through a Creative Commons Plus $(\mathrm{CC}+)$ commercial licensing construction considered as being "published for commercial purposes"?

- Can performers contractually waive their right to an equitable remuneration for communication to the public of commercial phonograms?

\footnotetext{
${ }^{1}$ The dispute led to two decisions of the Paris District Court ("Tribunal de grande instance de Paris" (TGI)) in 2015 (TGI Paris, 6 mars 2015, $\mathrm{n}^{\circ}$ 14/03917) and 2016 (TGI Paris, 18 Nov. 2016, ${ }^{\circ}$ 14/03917) and a decision of the Paris Court of Appeal ("Cour d'appel de Paris" (CA)) in 2018 (CA Paris, 6 avr. 2018, n ${ }^{\circ}$ 17/01312).

${ }^{2}$ Cass., 11 déc. 2019, $\mathrm{n}^{\circ}$ 18-21.211, ECLI:FR:CCASS:2019:C101021. For a translation of this decision, see this issue of IIC at https://doi.org/10.1007/s40319-020-00947-6.
} 
- Is mandatory collective management of the right to an equitable remuneration for communication to the public of phonograms published for commercial purposes compatible with EU law?

\section{Notion of "Phonograms Published for Commercial Purposes" and Creative Commons Plus (CC+) Commercial Licensing}

Are phonograms published through a Creative Commons Plus $(\mathrm{CC}+)$ commercial licensing construction considered as being "published for commercial purposes"? Yes

Only phonograms published for commercial purposes are concerned by the right to remuneration for communication to the public under Art. L214-1 of the French Intellectual Property Code (CPI). ${ }^{3}$ Thus, the Supreme Court, after establishing that Tapis Saint Maclou was communicating programmes to an indefinite number of potential listeners, and hence was making direct communication to the public in the sense of Art. 214-1 of the CPI, ${ }^{4}$ had then to examine whether the phonograms used were published for commercial purposes. The relevant parts of Art. L214-1 of the CPI read as follows: ${ }^{5}$

When a phonogram has been published for commercial purposes, neither the performer nor the producer may oppose:

$1^{\circ}$ its direct communication in a public place, where it is not used in a show; [...]

Such uses of phonograms published for commercial purposes, whatever the place of fixation of such phonograms shall entitle the performers and producers to remuneration.

This remuneration is paid by persons using the phonograms published for commercial purposes [...].

If the MusicMatic Group managed to prove that only phonograms published for non-commercial purposes were used in shops, the right to remuneration would not apply.

\footnotetext{
${ }^{3}$ In the EU, Art. 8(2) of the Rental and Lending Directive refers to phonograms published for commercial purposes. However, this legal text is interpreted as a minimum harmonisation requirement permitting Member States to broaden its scope. Some EU Member States do not limit this right to the phonograms published for commercial purposes and extend it to any phonograms. E.g., Croatia, Greece, Romania and Sweden, AEPO-ARTIS (2018), Performers' Rights in International and European Legislation: Situation and Elements for Improvement, p. 30.

${ }^{4}$ Under the terms of the contract, MusicMatic France undertook to provide stores of Tapis Saint Maclou with "MM Box" players, devices for communicating to the public musical programmes. According to the arguments made, such devices contained reproductions of phonograms, constituting a database of customisable programmes. On this basis, MusicMatic France unsuccessfully argued that such acts of reproduction of phonograms on devices and making these devices available to stores did not constitute the acts of "direct communication" to the public concerned by Art. L214-1 of the CPI.

5 Translation by the author. Emphasis added.
} 


\subsection{Creative Commons Non-Commercial (CC NC) Licences}

Creative Commons (CC) licences are public copyright licences for reproduction and communication to the public of works and subject-matter protected by copyright and related rights under standardised terms and conditions. ${ }^{6}$ The services of MusicMatic France to establishments open to the public relied on the music catalogue of Jamendo. Jamendo, by default, applied the most restrictive type of noncommercial CC licences, abbreviated as CC BY-NC-ND 3.0, to phonograms shared by performers. ${ }^{7}$ The prohibition of commercial use under the CC BY-NC-ND 3.0 licence is stipulated in its Sec. 4(b): "[The Licensee] may not exercise any of the rights granted to [it] in any manner that is primarily intended for or directed toward commercial advantage or private monetary compensation". 8 This brief provision leaves quite some room for interpretation of what constitutes "non-commercial" use. Within the CC community itself, some of the longest discussions and disagreements surround the question "What does NonCommercial mean?". 9 There is a brief CC guide on the interpretation of "non-commercial" that attempts to nonexhaustively clarify some aspects of the issue. ${ }^{10}$ For example, the guide makes it clear that the non-commercial requirement is addressed to uses and not to users. Hence, a for-profit organisation may use content licenced under the NC CC licence provided that the use is of non-commercial nature.

Are phonograms published under non-commercial CC licences "phonogram published for commercial purposes", in the sense of Art. L214-1 of the CPI? Neither the Supreme Court nor any of the lower instance courts dealt with this question. $^{11}$

The reasons for this is that the companies of the MusicMatic Group operated under a dual licensing model, offering phonograms under public non-commercial $\mathrm{CC}$ licences together with individual commercial licences permitting commercial uses (e.g. use in stores). Hence, the judgment refers to phonograms not under "pure" non-commercial CC licences but under the so-called Creative Commons Plus licensing construction.

\footnotetext{
${ }^{6}$ About CC licences, L. Lessig (2008), Remix: Making art and commerce thrive in the hybrid economy, London, UK: Bloomsbury, pp. 15 and 277-279 (the author developed CC licences); and S. Dusollier (2010), Scoping Study on Copyright and Related Rights and The Public Domain, WIPO Doc. No. CDIP/ 4/3/REV./STUDY/INF/1, pp. 52-56.

7 Jamendo, Legal, Creative Commons: https://www.jamendo.com/legal/creative-commons (last visited 1 April 2020). In short, "BY" refers to the requirement to credit the artist, "NC" prohibition of commercial use, and "ND" prohibition to mix or modify the work and/or phonogram.

${ }^{8}$ Creative Commons, Attribution-NonCommercial-NoDerivs 3.0 Unported (CC BY-NC-ND 3.0): https:// creativecommons.org/licenses/by-nc-nd/3.0/ (last visited 1 April 2020).

9 CC (2009), Defining "Noncommercial": A Study of How the Online Population Understands "Noncommercial Use".

${ }^{10} \mathrm{CC}$, NonCommercial interpretation: https://wiki.creativecommons.org/wiki/NonCommercial_ interpretation (last visited 1 April 2020).

${ }^{11}$ For a doctrinal interpretation to the contrary, see J. Huet (2020), "L'auto-producteur est triste : la Cour de cassation refuse de reconnaître le « libre » en musique", La Semaine Juridique, n 1-2, pp. 11-12.
} 


\subsection{Creative Commons Plus (CC+) Commercial Licensing}

Creative Commons Plus $(\mathrm{CC}+)$ denotes a combination of a $\mathrm{CC}$ licence with another separate and independent agreement granting more permissions (e.g. permitting commercial use and/or creation of derivative works). ${ }^{12}$ Here is a position of CC, the organisation promoting $\mathrm{CC}$ licences, with regard to a frequently asked question: "Can I still make money from a work I make available under a Creative Commons license?" Answer: "If someone else wants to use your work commercially and you have applied an NC [non-commercial] license to your work, they must first get your permission." 13

The business model of the MusicMatic Group companies relied on the possibility of $\mathrm{CC}+$ licensing. Jamendo, by default, offers creators to publish their music under a CC BY-NC-ND licence on its online platform. Individuals are welcome to use the music thus made available for free for their private use. ${ }^{14}$ The company creates profits by, among other things, selling additional permissions for using music in the Jamendo catalogue for synchronisation or as background music in establishments. To be able to do this, Jamendo has to first obtain additional permissions from the creators that initially published their music on its platform under the CC BY-NCND licence. Such additional permissions are managed through the licensing programme called Jamendo Licensing. Here is how the company describes it:

Thousands of composers on Jamendo have decided to make their music available for commercial use (in videos, or to be streamed in public places), as long as a licence has been acquired by the person willing to use the music. Those artists have joined a program called Jamendo Licensing, that allows them to distribute their work legally while protecting both their rights and those of the final user. ${ }^{15}$

Under the General Terms of Use of Jamendo services, "Jamendo Licensing" is defined as "the service enabling Artists to become involved in commercial Programs and/or promotional operations through partners of JAMENDO that may or may not remunerate Artists". ${ }^{16}$

In general, creators taking part in such licensing arrangements are self-published authors that are, at the same time, self-produced performers (i.e. qualified by law as phonogram producers) holding $100 \%$ of all rights to musical works and phonograms that they upload to the platform. Such rightholders are usually not members of any $\mathrm{CMO}$, since CMOs commonly require transfer or mandate of rights for commercial use.

\footnotetext{
12 CCPlus: https://wiki.creativecommons.org/wiki/CCPlus (last visited 1 April 2020).

13 Creative Commons, Frequently Asked Questions: https://creativecommons.org/faq/ (last visited 1 April 2020).

14 About this function of Jamendo platform, see also Europe Economics, L. Guibault, O. Salamanca and S. van Gompel (2016), Remuneration of authors and performers for the use of their works and the fixations of their performances, pp. 63 and 81.

15 Jamendo, Legal, License Details: https://www.jamendo.com/legal/licenses (last visited 1 April 2020). .

16 Jamendo, Legal, Terms of Use: https://www.jamendo.com/legal/terms-of-use (last visited 1 April 2020).
} 
It is clear that performers participating in the Jamendo Licensing programme, being interested in generating financial gains, release their phonograms for purposes other than those of the CC BY-NC-ND licences. Neither the Supreme Court nor lower instance courts scrutinised in detail $\mathrm{CC}+$ dual licensing in the reasoning of their judgments. The Supreme Court, by reaching the conclusion that Art. L214-1 of the CPI is applicable (and hence the phonograms concerned are published for commercial purposes), only stated that it took into account "the conditions under which Jamendo allows artists to publish their phonograms on its platform under a licence known as "Creative Commons"'. The Court did not merely refer to CC licences, which were non-commercial in the present case, but also evoked Jamendo's conditions. In light of everything aforementioned, all the supplementary licensing construction enabling commercial licensing played an important role in the decision. For this reason, this decision of the Supreme Court shall not be viewed as qualifying phonograms published only under non-commercial licences as "phonograms published for commercial purposes". The Court applied this qualification to a combination of noncommercial CC licences with commercial licences $(\mathrm{CC}+$ licensing). Communication to the public of phonograms published under such a $\mathrm{CC}+$ commercial licensing arrangement falls within the scope of Art. L214-1 of the CPI.

\section{Mandatory Collective Management of the Unwaivable Right to an Equitable Remuneration for Communication to the Public of Phonograms Published for Commercial Purposes}

\subsection{Unwaivable Nature of the Right to an Equitable Remuneration}

\section{Can performers contractually waive their right to an equitable remuneration for} communication to the public of commercial phonograms? - No

Since 2016, French law contains an explicit limitation of the transferability of the right of performers to an equitable remuneration for communication to the public of commercial phonograms. Article L212-11 of the CPI provides that when a performer transfers to a phonogram producer a claim to remuneration for the future use of his recorded performance in exchange for an advance payment, such transfer cannot include the right to remuneration for direct communication to the public of commercial phonograms. ${ }^{17}$ Any contractual clause to the contrary is null.

The Paris Court of Appeal established (and the Supreme Court did not question its finding) that the provisions of Art. L214-1 of the CPI are of mandatory nature, ${ }^{18}$ meaning that performers cannot be left without the right to remuneration by means of private contracts. On this basis, the Court of Appeal reached the conclusion that MusicMatic

\footnotetext{
17 The French provision is not unique in this regard, and legislation of some other countries, e.g. of Germany and the UK also limits the transfer of this right to remuneration with the aim of protecting performers. See Sec. 63a of the German Copyright Act (UrhG), making all statutory remuneration rights unwaivable, and Sec. 182 of the UK Copyright, Designs and Patents Act (CDPA), commented by H. Trubridge (2015), 'Safeguarding the Income of Musicians', WIPO Magazine, No. 2, p. 9.

18 Covered by the French legal concept of "ordre public", broader than its ordinary meaning in English.
} 
France, by relying on a waiver of the right to remuneration, misled its contracting party about the rights it had. Therefore, transferees of performers' exclusive rights cannot free users from the obligation to pay performers an equitable remuneration for direct communication of phonograms published for commercial purposes.

This finding is a result of the Courts' interpretation of Art. L214-1 of the CPI. Such unwaivable character of the right to remuneration is not explicitly spelled out in the CPI, and the above-mentioned limitation of transferability was added only in 2016. As a consequence, MusicMatic France could not obtain all the communication to the public rights to the phonograms it was providing to its clients for making background music.

In fact, Sec. 4(d)(i) of the CC BY-NC-ND 3.0 licence foresees the situation of statutory non-waivable remuneration rights:

Non-waivable Compulsory License Schemes. In those jurisdictions in which the right to collect royalties through any statutory or compulsory licensing scheme cannot be waived, the Licensor reserves the exclusive right to collect such royalties for any exercise by [the licensee] of the rights granted under this License. $^{19}$

However, the collection of remuneration of performers and phonogram producers for communication to the public of phonograms published for commercial purposes is subject to mandatory collective management in France. The MusicMatic Group tried to dispute the compatibility with EU law of this collective management mechanism, with the aim to enable rightholders to reserve the collection of remuneration or to exercise it on their behalf.

\subsection{Compatibility of Mandatory Collective Management of the Right to Remuneration with EU Law}

Is mandatory collective management of the right to an equitable remuneration for communication to the public of phonograms published for commercial purposes compatible with EU law? - Yes

Article L214-5 of the CPI states that: "The remuneration provided by Article L214-1 is collected for rightholders and distributed among them by one or several collective management organisations [...]." Such form of exercise of rights, where they could only be exercised by a CMO, is commonly referred to in legal doctrine as mandatory collective management. The MusicMatic Group questioned the compatibility of this mechanism with EU law.

SPRE (Société pour la perception de la rémunération équitable) is the CMO whose sole task is the collection of an equitable remuneration for communication to

\footnotetext{
19 Emphasis added. For a comment on this provision, C. Angelopoulos (2011), 'Creative Commons and Related Rights in Sound Recordings: Are the Two Systems Compatible?', in L. Guibault and C. Angelopoulos (eds.), Open Content Licensing: From Theory to Practice, Amsterdam, Netherlands: Amsterdam University Press, pp. 245 (fn. 3), 284 and 285.
} 
the public for the benefit of performers and phonogram producers. In 2010, the Commission, established under Art. L214-4 of the CPI to determine tariffs and payment modalities of the equitable remuneration, decided that users shall provide all the information necessary for the determination of the remuneration to SPRE or an organisation mandated by it. ${ }^{20}$ SACEM, the CMO managing rights to musical works, was mandated by SPRE to collect remuneration from establishments with background music open to the public. ${ }^{21}$ This is why it was SACEM, the CMO of music authors and publishers, who sent a claim to Tapis Saint Maclou in 2013, and why the contract between MusicMatic France and Tapis Saint Maclou contained a guarantee specifically referring to copyright claims by SACEM.

SPRE is an umbrella CMO of CMOs representing performers and phonogram producers. No performer or phonogram producer can become its member or directly receive remuneration from it. SPRE transfers all the collected amounts to the CMOs representing performers and phonogram producers for further distribution to rightholders concerned.

Due to the structure of the described system, equitable remuneration is collected from establishments using background music by a CMO different from the CMO designated by the Commission under Art. L214-4 of the CPI, and four other CMOs, which do not collect the remuneration, distribute it to performers and phonogram producers. No individual performer or phonogram producer can become a member of the $\mathrm{CMO}$ collecting remuneration or exercise individually his right to remuneration.

The MusicMatic Group questioned this system and requested the courts to refer the following two questions for a preliminary ruling to the Court of Justice of the European Union (CJEU):

Question 1: Do Articles 8(2) and 10(2) and (3) of the Directive 2006/115 [Rental and Lending Directive ${ }^{22}$ ] prevent national provisions of a member state such as Article L214-5 of the CPI that provides for mandatory and systematic collection of the equitable remuneration by a CMO even for performers and/or phonogram producers that are not members of the CMO?

Question 2: Do Articles 8(2) and 10(3) of the Directive 2006/115 prevent a national provision such as Article L214-5 of the CPI resulting in the situation

\footnotetext{
${ }^{20}$ Article 7 of the Décision du 5 janvier 2010 de la commission prévue à l'article L. 214-4 du code de la propriété intellectuelle.

21 About this relationship between the two CMOs, L. Reguera, B. Muñoz, N. Pozo et al. (2019), Agreement on a New Single License Model for In-Store Audio Systems for European Collecting Societies, V1.0, ABC_DJ Consortium, p. 14. For more detailed information about collection services that SACEM provides to SPRE since 1990, see a report of the French national competent authority supervising CMOs (Commission de contrôle des organismes de gestion des droits d'auteur et des droits voisins, Quinzième rapport annuel, Avril 2018, pp. 172 and 246) and an article of the former Chief Legal Officer of SPRE (N. Kaleski (2009), Sociétés de perception et de répartition des droits : Société pour la perception de la rémunération équitable de la communication au public des phonogrammes du commerce (SPRE), JurisClasseur Propriété littéraire et artistique, Fasc. 1586, paras. 2 and 9).

22 Directive 2006/115/EC of the European Parliament and of the Council of 12 December 2006 on rental right and lending right and on certain rights related to copyright in the field of intellectual property (codified version) [2006] OJ L 376/28.
} 
when performers and phonogram producers non-members of CMOs, whose phonograms published for commercial purposes are used for communication to the public, do not receive an equitable remuneration because it is not being distributed to them while being systematically and mandatorily collected from users?

The claimants also alleged a disproportionate and non-justified limitation of the right to property under Art. 1 of Protocol 1 to the European Convention on Human Rights. $^{23}$

All the courts refused to refer these questions to the CJEU. As the Supreme Court did not offer such written reasoning for its decision in this regard, the reasons put forward by the Paris Court of Appeal could be of some use.

With regard to the first of the two aforementioned questions, the Court of Appeal cited Art. 9 of the Satellite and Cable Directive, ${ }^{24}$ Art. 5 of the Rental and Lending Directive, and Recitals 2 and 12 of the Collective Management Directive, as examples of the permissibility of mandatory collective management under EU law. According to the Court, the Rental and Lending Directive does not regulate how the right to an equitable remuneration is implemented. The Court concluded that there were no grounds for requesting the CJEU to interpret a provision that does not exist, as the referral to the CJEU cannot have as its subject new obligations or prohibitions not provided by the Directive.

With regard to the second question, the Court based its refusal on the fact that Art. L214-1 of the CPI does not require rightholders to be members of a CMO in order to benefit from the right to an equitable remuneration collected collectively. The Court also established that the statutes of ADAMI (Société pour l'administration des droits des artistes et musiciens-interprètes) and SPEDIDAM (Société de perception et de distribution des droits des artistes-interprètes), CMOs distributing collected remuneration to performers, do not require performers to become their members to benefit from the remuneration. Furthermore, the Court took into account the written declarations of the CMOs and an annual report of SPEDIDAM stating that they effectively distribute remuneration to rightholders non-members. ${ }^{25}$ The Court considered this evidence sufficient and judged that the other side did not present convincing evidence to the contrary.

The reaffirmation of the rule of mandatory collective management implied that the argument of MusicMatic France that an equitable remuneration had already been paid by Tapis Saint Maclou via the programme Jamendo Licensing "In-Store" and distributed to performers by Jamendo could not be accepted. It is curious to observe

\footnotetext{
${ }^{23}$ In the first instance, MusicMatic France also made unsuccessful claims about violation of the constitutional principle of equality, freedom to conduct a business and right to property, requesting a preliminary ruling on constitutionality ("question prioritaire de constitutionnalité") by the Constitutional Court ("Conseil constitutionnel"). .

24 Council Directive 93/83/EEC of 27 September 1993 on the coordination of certain rules concerning copyright and rights related to copyright applicable to satellite broadcasting and cable retransmission [1993] OJ L 248/15.

25 Interestingly, the Court did not carry out the same scrutiny of statutes and practices of the CMOs distributing remuneration to phonogram producers. Self-recorded performers are also producers, and hence are entitled to the statutory performer's and producer's share of the remuneration.
} 
that in February 2019 Jamendo obtained the independent management entity (IME) status under Luxembourgish law transposing the Collective Management Directive. $^{26}$ IMEs are essentially for-profit entities performing the same or similar rights management activities as CMOs. ${ }^{27}$ However, only CMOs can manage rights subject to mandatory collective management in France.

The CPI, Art. L214-5 of which imposes mandatory collective management of the right to an equitable remuneration, is not explicit on how this form of rights exercise concerns the rights of rightholders non-members (i.e. rightholders who have not directly or indirectly explicitly authorised a CMO to manage their rights). One way to understand the rule could be that the right to remuneration can be exercised only collectively, CMOs could exercise only the rights of their members, and it is for rightholders to decide whether they would like to join a $\mathrm{CMO}$ for their rights to be exercised. The present case makes it clear that the right of performers and phonogram producers to an equitable remuneration for communication to the public of commercial phonograms is managed collectively even when they are not members of a CMO. This decision does not affect the existing practice and arrangements of collective management in the domain, but it reinforces and clarifies their legality.

In the broader EU context, in most Member States, the right of performers and/or phonogram producers to remuneration for broadcasting and/or other communication to the public of phonograms is subject to mandatory collective management: Austria, Belgium, Croatia, Czech Republic, Denmark, Estonia, France, Germany, Greece, Hungary, Ireland, Italy, Latvia, Lithuania, Luxembourg, Netherlands, Poland, Portugal, Romania, Slovakia, Slovenia, Spain and Sweden. ${ }^{28}$ It does not seem that the CJEU, if requested to make a preliminary ruling on the compatibility with EU law of mandatory collective management of the right to an equitable remuneration for communication to the public of commercial phonograms, would declare it incompatible. Aside from the long widespread practice, the determining factor for such a decision would be the nature of the rights in question. When comparing the exclusive right of authors and the remuneration right of performers and phonogram producers in the context of communication to the public, the CJEU

\footnotetext{
26 AudioValley, Jamendo adopte le statut d'Entité de GestionIndépendante, Communiqué de presse, 13 February 2019: https://www.audiovalley.com/wp-content/uploads/2020/01/cp-audiovalley-20190213jamendoegi-vdef.pdf (last visited 1 April 2020).

27 Article 3(b) of the Collective Management Directive.

28 AEPO-ARTIS (2018), Performers' Rights in International and European Legislation: Situation and Elements for Improvement, pp. 26-29 (referring to Austria, Belgium, Croatia, Czech Republic, France, Greece, Hungary, Italy, Latvia, Lithuania, Netherlands, Poland, Portugal, Romania, Slovenia and Spain); M. Ficsor and M. Chatalbashev (2016), 'Collective Management in Central and Eastern Europe', in D. Gervais (ed.), Collective Management of Copyright and Related Rights, 3rd edn., Alphen aan den Rijn, Netherlands: Kluwer Law International, p. 128 (referring to Croatia, Czech Republic, Hungary, Latvia, Romania and Slovakia); and KEA European Affairs (2006), The Collective Management of Rights in Europe: The Quest for Efficiency, conducted on request of the European Parliament's Committee on Legal Affairs, IP/C/JURI/ST/2005-90, p. 66 (referring to Austria, Belgium, Czech Republic, Denmark, Estonia, Greece, Hungary, Ireland, Italy, Latvia, Lithuania, Luxembourg, Netherlands, Poland, Portugal, Slovakia, Slovenia, Spain and Sweden). A comprehensive mapping of mandatory collective management in EEA member states is currently being prepared by ECORYS and IViR under SMART 2018/0069 contract with the European Commission.
} 
already established that the exclusive right is "preventive," whereas the latter is merely "compensatory" 29 and "financial" 30 in nature. The prerogative to control (authorise or prohibit) non-interactive communication to the public of phonograms is not a part of the right of performers and phonogram producers to receive remuneration. Mandatory collective management could be more easily accepted as a way to implement this remuneration right.

\section{Conclusions}

The decisions at the French Supreme Court and lower instance courts in the proceedings opposing the MusicMatic Group of companies, including Jamendo, and CMOs representing performers and phonogram producers, clarified some important aspects of the right to an equitable remuneration for communication to the public of phonograms published for commercial purposes and its exercise.

First, the Supreme Court qualified phonograms published through a Creative Commons Plus $(\mathrm{CC}+)$ licensing arrangement, combining non-commercial Creative Commons and commercial licensing through the Jamendo platform, as being "published for commercial purposes". It is important to underline that the Court did not make any qualification regarding phonograms released under non-commercial Creative Commons licences alone.

Second, the Court established that the right to remuneration is an unwaivable right of performers. As the right cannot be waived, transferees of performers exclusive rights cannot contractually free users from the obligation to pay the remuneration. On this basis, the Court judged the contractual statement on the provision of music "free of public communication rights" to be misleading. The unwaivable character of the rights is not explicitly written in the statuary law and was established through its interpretation by the Court.

Third, the remuneration cannot be collected on behalf of and for performers by any party other than a competent CMO. The CMO is empowered to collect remuneration for all rightholders, including those who have not authorised it directly or indirectly (through another CMO). The decision reinforced the existing practice. The Court judged the mechanism of mandatory collective management of performers' and phonogram producers' rights to an equitable remuneration for communication to the public of phonograms published for commercial purposes to be compatible with EU law.

Open Access This article is licensed under a Creative Commons Attribution 4.0 International License, which permits use, sharing, adaptation, distribution and reproduction in any medium or format, as long as you give appropriate credit to the original author(s) and the source, provide a link to the Creative Commons licence, and indicate if changes were made. The images or other third party material in this article are included in the article's Creative Commons licence, unless indicated otherwise in a credit line to the material. If material is not included in the article's Creative Commons licence and your intended use is not permitted by statutory regulation or exceeds the permitted use, you will need to obtain

\footnotetext{
${ }^{29}$ CJEU Judgments in Judgment in Reha Training, C-117/15, ECLI:EU:C:2016:379, para. 30, and SCF, C-135/10, ECLI:EU:C:2012:140, para. 75.

30 CJEU Judgment in SCF, C-135/10, ECLI:EU:C:2012:140, paras. 77 and 89.
} 
permission directly from the copyright holder. To view a copy of this licence, visit http:// creativecommons.org/licenses/by/4.0/.

Publisher's Note Springer Nature remains neutral with regard to jurisdictional claims in published maps and institutional affiliations. 